\title{
Exploring low-carbon landscape design: focus on an urban waterfront area
}

\author{
J. Chon, Y. Eui Choi, S. Jin You, H. Ji Lee \& Y. Sun Seok \\ Department of Environmental Science and Ecological Engineering, \\ Korea University, Korea
}

\begin{abstract}
Sustainable designs like low-carbon landscapes are key to lowering the anthropogenic carbon footprint of our society and promoting harmony with natural ecosystems. We can design low-carbon landscapes for terrestrial (e.g. forests and urban farming areas) as well as aquatic (e.g. urban streams, ponds, and wetlands) urban spaces. Ecological interactions between water and soil in an urban ecosystem cause high carbon accumulation rates, especially in waterfront areas. Furthermore, heat absorption at waterfronts also significantly mitigates urban heat island effect. Therefore, urban open spaces with waterfronts are ecologically vital and may help us cope with climate change. However, the design and application of urban low-carbon landscapes are still in the conceptual phase and the creation a low carbon city remains as a preliminary draft. At present, there are very few studies measuring carbon emissions and carbon absorptions in the urban area. Moreover, studies that analyze low-carbon landscape components and their social effects are needed. In this study, we propose a novel conceptual definition of low-carbon landscape and investigate the research methods related to low-carbon landscape design. We have also listed numerous case studies of urban waterfronts scrutinizing the various components of a low-carbon landscape.

Keywords: design elements, low-carbon society, carbon reduction, carbon sequestration.
\end{abstract}

\section{Introduction}

Korea's high carbon footprint gained significant global and national notoriety after it became a signatory to the United Nations Framework Convention on 
Climatic Change (UNFCCC). Moreover, significant amounts of greenhouse gases were being released due to urban economic activities. We are going to be tasked with reducing our $\mathrm{CO}_{2}$ emissions based on the terms of the treaty (Lee and Lee [1]). Subsequently, the Korean government established and implemented policies like the "Five-year Plan for Green Growth" and "Urban Planning Guideline for the Development of Green City" (Park and Kim [2], Ko et al. [3]). Furthermore, legislations like "Framework Act on Low Carbon and Green Growth" were also introduced in 2010 to deal with global climate change (Yeo and Yoon [4]). Two critical elements that are often discussed while considering sustainable urban development as a response to systemic disruptions in Korea resulting from climate change are environmental sustainability and energy efficiency. Consequently, interest in introducing greenhouse gas reduction measures to urban areas grew (NGMS [5]). In order to address these problems and to achieve low carbon society, the concept of "low carbon landscape" was proposed. A low carbon landscape includes landscape elements composed of materials and facilities, which can reduce greenhouse gas emissions and minimize the overall carbon footprint (Zhang and Sui [6]). Since low carbon landscapes are one of the core elements that can reduce the greenhouse emissions (Huifang et al. [7]); these can be grouped along with other terrestrial (i.e. urban forests, parks, and urban agriculture spaces) and aquatic features (i.e. the waterfronts like rivers, ponds and wetlands). Waterfronts tend to have a high carbon accumulation rate due to systemic interaction between water and soil. Furthermore, waterfronts play a critical role (Lee [8], UNEP [9]), in mitigating urban heat island effect. However, fundamental research evaluating the design elements and criteria for low carbon landscape resources specific to urban waterfront is currently in the concept formulation phase. Using case studies, we have investigated low carbon landscape design elements for an urban waterfront. Moreover, we propose a novel conceptual definition of low-carbon landscape and state the criteria for low carbon landscape design.

\section{Literature review}

\subsection{Related research trend}

Interest in low carbon landscapes in Korea grew after the National Climate Change Adaptation Plan was established in 2008 to achieve the nation's vision of low carbon and green growth policy. In 2009, the Korea government declared it was planning an energy saving city utilizing new renewable energy sources along with Ministry of Land, Infrastructure and Transport (Kim [10], Park and Kim [2]). In order to do this, the elements of low carbon landscape needed to be actively utilized. Moreover, qualified evaluation of means and methods was needed before adopting new renewable energy sources. However, in Korea, assessment tools for planning and designing low carbon landscape are nonexistent; making the detailed analysis of energy savings impossible (Lee and Lee [1]). Nevertheless, in order to compensate for this analytical difficulty, ecological and environment sectors have actively performed independent studies 
that evaluate whether urban green space reduces the $\mathrm{CO}_{2}$ concentrations (Ahn et al. [11]). These field studies were performed to ascertain the carbon reduction in the atmosphere based on tree carbon fixation calculations (Jo and Ahn [12], Park and Kang [13], Ahn et al. [11], Jo and Ahn [14]). However, such field studies are usually performed in metropolitan areas or forest ecosystems and focus on various technical aspects, often neglecting the hydro-ecosystem. The reason for the technical orientation of these studies is that Korean water resource development significantly affects irrigation planning of our rivers. Whereas, other countries had long recognized waterfronts like streams and wetlands as a method for greenhouse gas reduction and evaluated their carbon storage capacity and emissions from wetland soil. Furthermore, the use and management methods for waterfront design elements are also studied (Neue et al. [15], Persson [16], IPCC [17], Timothy and Paul [18]). Consequently, further research, which would provide insights into policy, design, planning, and management for low carbon landscape using technical data like absorption and evapotranspiration of $\mathrm{CO}_{2}$, is needed.

\subsection{Definition of low-carbon landscape design}

Low carbon landscapes were specifically proposed for incorporation into 'low carbon cities,' and were first used in many countries including Oceania, China, and Taiwan; which respond sensitively to climate change (Zhang and Sui [6], Beringer et al. [19], Huifang et al. [7], Zhou et al. [20]). Many studies define low carbon landscapes as spaces to assimilate nature in the process of landscape design and formation. Using landscape design model slow carbon landscapes have been shown to reduce the use of non-renewable energy by reducing energy consumption, pollution, and emissions while increasing carbon fixation rates (Huifang et al. [7]). However, very few case studies pertaining to design of low carbon landscapes exist since low carbon landscape design is still in its conceptual phase. This study establishes the concept of low carbon landscape by defining 'low carbon' and 'landscape' using peer-reviewed literature. "The Framework Act on Low Carbon, Green Growth" defines the usage of the term 'low carbon' as reducing the dependence on fossil fuels, increasing the use and supply of clean energy, and reducing the greenhouse gas concentration below the optimum level through research and development as well as increasing carbon absorption. Landscapes are a means of expressing the local environmental, visual and aesthetic characteristics composed by nature, artificial elements, and residential life style (Lee [21]). Therefore, 'low carbon landscapes' should be composed of elements necessary to reduce the greenhouse effect, cope with climate change, and make a low carbon city tangible. These elements can be predominantly classified as carbon reduction and carbon sequestration based on the $\mathrm{CO}_{2}$ reduction method (table 1). 
Table 1: $\quad$ The classification standard for low carbon landscape.

\begin{tabular}{|c|c|c|c|}
\hline \multicolumn{2}{|r|}{ Carbon reduction } & \multicolumn{2}{|c|}{ Carbon sequestration } \\
\hline \multirow{8}{*}{$\begin{array}{l}\text { Energy } \\
\text { conservation }\end{array}$} & $\begin{array}{c}\text { Installing high performance } \\
\text { insulation and keeping buildings } \\
\text { airtight }\end{array}$ & \multirow[t]{2}{*}{ Complex greenery } & Carbon park \\
\hline & $\begin{array}{c}\text { Considering solar and building } \\
\text { orientation }\end{array}$ & & Vegetable garden \\
\hline & Bicycle activating system & \multirow{2}{*}{$\begin{array}{l}\text { 3-dimensional } \\
\text { planting }\end{array}$} & Roof planting \\
\hline & Pedestrian road & & Wall planting \\
\hline & Transit transfer center & \multirow{4}{*}{ Green network } & Greenway \\
\hline & $\begin{array}{c}\text { Public transportation and } \\
\text { pedestrian mall }\end{array}$ & & Ventilation path \\
\hline & $\begin{array}{l}\text { Carbon reduction public } \\
\text { transportation }\end{array}$ & & Carbon forest \\
\hline & Green highway & & Eco bridge \\
\hline \multirow{4}{*}{$\begin{array}{l}\text { Renewable } \\
\text { energy }\end{array}$} & Photovoltaic system & \multirow{2}{*}{$\begin{array}{l}\text { Water resource } \\
\text { system }\end{array}$} & Brooklet \\
\hline & Solar thermal system & & Detention ponds \\
\hline & Passive solar system & \multirow{2}{*}{$\begin{array}{l}\text { Water circulation } \\
\text { system }\end{array}$} & Natural soil \\
\hline & Small scale cogeneration system & & Porous pavement \\
\hline \multirow{4}{*}{$\begin{array}{l}\text { Recycling } \\
\text { resources }\end{array}$} & Using natural resources & \multirow{4}{*}{ Waterfront } & Wetland \\
\hline & Recycling heavy water & & Rain garden \\
\hline & Storm water & & Wildlife habitats \\
\hline & $\begin{array}{l}\text { Recycling storm water storage } \\
\text { tank }\end{array}$ & & Natural river \\
\hline
\end{tabular}

Data: Yoon [22]: Author Rewriting.

\subsection{The classification standard for low carbon landscape}

\subsubsection{Carbon reduction}

Carbon reduction can be achieved by introducing low carbon tourism and creating sustainable tourist allurement, the naturalism, and idealism (Costa and Soares [23]). Using renewable energy sources such as wind power should also be encouraged. Reducing the carbon footprint does not necessarily mean the carbon emission reductions. It may also be accomplished by offsetting carbon emissions using the dynamic carbon balance (ASQASKETS [24]). Various alternatives which use carbon reduction for accomplishing the balance of $\mathrm{CO}_{2}$ are known (Ko et al. [3]). Urban traffic system with green transportation and virtuous circulation system that encourages walking and bicycling are vital for carbon reduction (Seo [25]). Furthermore, buildings retrofitted for small to medium wind power generation along with a passive solar power generation system are a norm in Korea (Rural Development Administration [26]).

\subsubsection{Carbon sequestration}

Carbon sequestration means to absorb the thermal energy using a green roof system and the insulation effect achieved by planting vegetation. Similarly, urban street trees, eco corridors, wetlands, village forest development, and rain gardens can be used to absorb $\mathrm{CO}_{2}$ (Costa and Soares [23]). 


\section{Case study}

\subsection{Outline of case study}

This final phase study investigates low carbon landscape resources composed of typical waterfront areas of four new low carbon footprint towns. First, we analyzed the general details, the topographic characteristic, and the condition of water resources to understand the new town. Secondly, we investigated the low carbon landscape resources at the waterfront of the new town, and classified them as carbon sequestration or carbon emission (fig. 1).

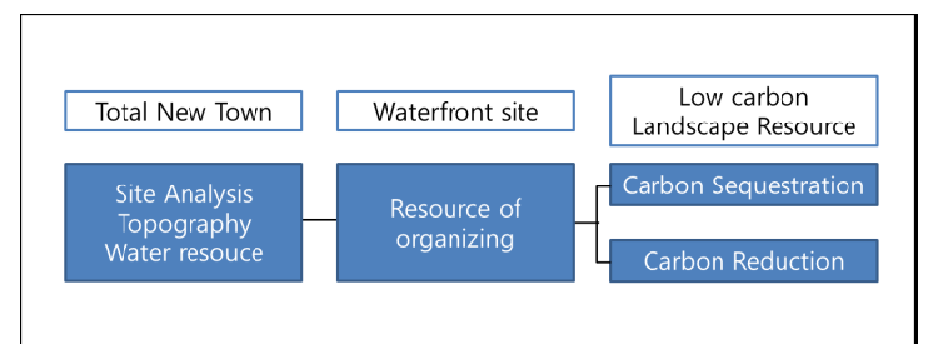

Figure 1: $\quad$ Outline of case study.

\subsection{Unjeong New Town}

Unjeong New Town is located in Dongpae-ri, Mokdong-ri, Yadang-ri, Wadongri, Dangha-ri, Sangiiseok-ri, Dayul-ri, and Gyoha-ri in Paju-si, Gyeonggi-do (Korea Housing Corporation [27]). The New Towns are planned cities, which incorporate a water circulation system that will cope with climate change and create a sustainable urban environment improving the quality of life for urban residents. Topographically, the Unjeong New Town has an east to west slope. Gamaksan, Papyeongsan, and Gyemyeongsan are located to the eastern side of Unjeong New Town. Since about $80.2 \%\left(539.67 \mathrm{~km}^{2}\right)$ land is under the altitude of $100 \mathrm{~m}$ large areas are available for development. The dimensional stability of Sori-stream was considered since both the Sori-stream as well as the river, overflowed in the 1996, 1998, and 1999 because of their flat topography. Furthermore, contamination of Sori-stream, which is used for drainage way, was common in the dry season. Consequently, river maintenance became essential and the Sori-stream implementation project was established in November 2006. The Sori-stream is the primary axis of the water circulation system of Unjeong New Town; while the brooklet, which circulates in the residential area, is the secondary axis. The space organization is composed of the water sports zone, the waterway zone, and the eco zone. The main contents are listed in table 2.

The carbon reduction and carbon sequestration components of waterfront area in the Unjeong New Town are listed in table 3. 
Table 2: $\quad$ Unjeong New Town waterfront plan.

\begin{tabular}{|l|l|}
\hline \multicolumn{1}{|c|}{ Zone } & \multicolumn{1}{c|}{ Contents } \\
\hline Water sports zone & $\begin{array}{l}\text { - The creation of the waterfront site based on natural landscape } \\
\text { - Continuous rapids type drop structure } \\
\text { - Provide the function of fish migration }\end{array}$ \\
\hline Waterway zone & $\begin{array}{l}\text { - The adjustment of river width accounting for flooding } \\
\text { - Urban natural river planning }\end{array}$ \\
\hline Eco zone & $\begin{array}{l}\text { - Use of existing water system } \\
\text { - The composition of eco friendly techniques } \\
\text { - Rainwater harvesting, plant and wildlife habitat } \\
\text { - Creating an eco pond }\end{array}$ \\
\hline
\end{tabular}

Data: Korea Environment Institute [28].

Table 3: $\quad$ Unjeong New Town low carbon landscape resources.

\begin{tabular}{|l|l|l|c|}
\hline \multicolumn{2}{|c|}{ Carbon reduction } & \multicolumn{2}{c|}{ Carbon sequestration } \\
\hline \multirow{4}{*}{$\begin{array}{l}\text { Resource } \\
\text { circulation }\end{array}$} & $\begin{array}{l}\text { 3-dimensional } \\
\text { Planting }\end{array}$ & Slope vegetation \\
\cline { 3 - 4 } & Storm water & $\begin{array}{l}\text { Water resource } \\
\text { System }\end{array}$ & Brooklet \\
\cline { 3 - 4 } & & $\begin{array}{l}\text { Water circulation } \\
\text { System }\end{array}$ & Detention ponds \\
\cline { 3 - 4 } & & Porous pavement \\
\cline { 3 - 4 } & Waterfront & $\begin{array}{c}\text { Natural river (Riffle, } \\
\text { pond, natural-stone } \\
\text { masonry) }\end{array}$ \\
\hline
\end{tabular}

\subsection{Pangyo New Town}

Sungnam-Si developed the Pangyo New Town in order to control the sprawling development after construction restrictions were cancelled and to establish sustainable urban planning (Korea Housing Corporation [29]). The development range of Pangyo New Town includes Pangyo-dong, Hasanun-dong, Unjungdong, Sampyeong-dong, Baekhyeon-dong, Imae-dong, Yatap-dong, Seohyeondong and Sunae-dong in Bundang-gu, and Sujeong-gu, Sasong-dong, Geumtodong in Sujeong-fu in Seongnam-si, Gyeonggi-do. The total development area is about $9,294 \mathrm{~m}^{2}$. Topographically, Pangyo New Town is predominantly flat land. Subsequently, forests were created in the Meogeum Mountain near from the north side adjoining Seoul Ring Expressway, Geumto Mountain located at the center of site, and the Shinchon-park area of the south side. The Unjung and Geumto streams, which are the principal water resources in Pangyo run from west to east. The Hasan and Seongnaemi streams merge into the Unjung stream (Korea Housing Corporation [30]). The Pangyo New Town has a significant advantage for installing the water circulation system because of the artificial wetlands and agriculture waterways around the rural region of Unjung and Geumto stream. Table 4 lists the planning components of the water circulation system installed in the Pangyo New Town. 
Table 4: $\quad$ Pangyo New Town water circulation system plan.

\begin{tabular}{|l|l|}
\hline \multicolumn{1}{|c|}{ Plan } & \multicolumn{1}{c|}{ Contents } \\
\hline $\begin{array}{l}\text { Using existing water } \\
\text { system }\end{array}$ & $\begin{array}{l}\text { - Arrangement of district site considering existing water system } \\
\text { - Tandem operation of the water system with natural mountain flow } \\
\text { system }\end{array}$ \\
\hline \multirow{2}{*}{ Use of storm water } & $\begin{array}{l}\text { - Storm water was retained by the detention pond inside the park as } \\
\text { well as the complex } \\
\text { - Connecting private and public storm water drainage }\end{array}$ \\
\hline \multirow{2}{*}{ Reusing groundwater } & $\begin{array}{l}\text { - The utilization of groundwater seepage during the construction of } \\
\text { the subway and underground. } \\
\text { - Reusing groundwater seepage from subways or underpass }\end{array}$ \\
\hline
\end{tabular}

Data: Korea Environment Institute [28].

The space organization is such that the brooklet is connected to the public space, neighborhood park, and the detention pond. The components of the waterfront in the complex and Water Restoration Center are listed in table 5.

Table 5: $\quad$ Pangyo New Town waterfront plan.

\begin{tabular}{|l|ll|}
\hline \multicolumn{1}{|c|}{ Zone } & \multicolumn{1}{c|}{ Components } \\
\hline Brooklet & $\begin{array}{l}\text { - Water station } \\
\text { - Observatory } \\
\text { - Planting within the stream }\end{array}$ \\
\hline Waterfront in complex & - Wetland & - Habitat \\
\hline Water Restoration Center & - Treatment and discharge of residential sewage \\
\hline
\end{tabular}

Data: Korea Environment Institute [28]

The carbon reduction and carbon sequestration components of waterfront area in the Pangyo New Town are listed in table 6.

Table 6: $\quad$ Pangyo New Town low carbon landscape resources.

\begin{tabular}{|c|c|c|c|}
\hline \multicolumn{2}{|c|}{ Carbon reduction } & \multicolumn{2}{|c|}{ Carbon sequestration } \\
\hline \multirow{4}{*}{$\begin{array}{l}\text { Energy } \\
\text { conservation }\end{array}$} & Bicycle activating system & \multirow{2}{*}{$\begin{array}{l}\text { Complex } \\
\text { greenery }\end{array}$} & Carbon park \\
\hline & Pedestrian road & & Vegetable garden \\
\hline & $\begin{array}{c}\text { Public transportation and } \\
\text { pedestrian mall }\end{array}$ & $\begin{array}{l}\text { 3-dimensional } \\
\text { planting }\end{array}$ & Roof planting \\
\hline & $\begin{array}{l}\text { Carbon reduction public } \\
\text { transportation }\end{array}$ & \multirow{2}{*}{ Green network } & Ventilation path \\
\hline \multirow{4}{*}{$\begin{array}{l}\text { Resource } \\
\text { recycling }\end{array}$} & Existing water system & & Eco bridge \\
\hline & Recycling heavy water & \multirow{2}{*}{$\begin{array}{l}\text { Water resource } \\
\text { system }\end{array}$} & Brooklet \\
\hline & Storm water & & Detention ponds \\
\hline & $\begin{array}{l}\text { Recycling storm water storage } \\
\text { tank }\end{array}$ & \multirow{4}{*}{ Waterfront } & Wetland \\
\hline \multirow{3}{*}{\multicolumn{2}{|c|}{-}} & & Rain garden \\
\hline & & & Wildlife habitats \\
\hline & & & Natural river \\
\hline
\end{tabular}




\subsection{Gimpo Han River New Town}

Gimpo Han River New Town was developed with the purpose of developing a green eco-city, solving housing shortages, and creating a comfortable environment in the metropolitan area (Korea Land Corporation [31]). The development range included Janggi-dong, Woonyang-dong and Yangchonmyeon of Gimpo-si and Korea Land. The Housing Corporation took over operational responsibilities after the development areas were designated as Housing Development district in 2006. The topography of Gimpo Han River New Town is both hilly as well as flat. The altitude around Unyusan is approximately $70 \mathrm{~m}$, while Daemasan and Modansan are relatively flat $(20 \mathrm{~m})$ and occupy about $70 \%$ of the total area. Most of the site is a plain area and the plow land occupies over $50 \%$ of the site. The shape of this site is long from east to west and has a valley. The Gamaji stream and the Gimpo waterway merge into the Han River in the business district. The Gamaji stream originates in the urban south side and flows into the Han River where it meets the Beopseongpo stream of the north side. The Gimpo waterway is also used for irrigation. It is feasible to develop it as a waterfront zone through reorganization and securing an additional water source. The Gimpo Han River New Town is divided into the complex business district, cultural exchange district, and ecological environment district. The waterfront area is composed of the eco canal zone, an ecological park for the wild birds zone, and the canal zone (table 7).

The carbon reduction and carbon sequestration components of the waterfront area in the Gimpo Han River New Town are listed in table 8.

Table 7: $\quad$ Gimpo Han River waterfront plan.

\begin{tabular}{|l|l|}
\hline \multicolumn{1}{|c|}{ Zone } & \multicolumn{1}{c|}{ Components } \\
\hline Eco canal & $\begin{array}{l}\text { - Development of the ecological environment observation program } \\
\text { - The selection of the waterfront site which connects with the eco-canal } \\
\text { - The creation of the shore and gentle slopes } \\
\text { - The installation of a pumping station and rainwater recycling facility }\end{array}$ \\
\hline $\begin{array}{l}\text { Ecological } \\
\text { park for wild birds }\end{array}$ & $\begin{array}{l}\text { - Wild bird's habitat composition } \\
\text { - Build the eco center }\end{array}$ \\
\hline Culture & - Hydrologic and water pollution control facilities \\
\hline
\end{tabular}

Data: Korea Environment Institute [28].

Table 8: Gimpo Han River New Town low carbon landscape resources.

\begin{tabular}{|c|c|c|c|}
\hline \multicolumn{2}{|r|}{ Carbon reduction } & \multicolumn{2}{|c|}{ Carbon sequestration } \\
\hline \multirow{4}{*}{$\begin{array}{l}\text { Energy } \\
\text { Conservation }\end{array}$} & Mud cap house & \multirow{2}{*}{$\begin{array}{l}\text { Water } \\
\text { resource } \\
\text { system }\end{array}$} & Brooklet \\
\hline & Pedestrian road & & Detention ponds \\
\hline & Public transportation and pedestrian mall & \multirow{4}{*}{ Waterfront } & Wetland \\
\hline & Green highway & & Rain garden \\
\hline \multirow{3}{*}{$\begin{array}{l}\text { Resource } \\
\text { recycling }\end{array}$} & Recycling heavy water & & Wildlife habitats \\
\hline & Storm water & & Natural river \\
\hline & Recycling storm water storage tank & & - \\
\hline
\end{tabular}




\subsection{Gwanggyo New Town}

Gwanggyo New Town is planned as metropolitan area and a southern central city. It was designed to be eco-friendly and incorporated education or research hubs, sport and leisure complexes. It is also a vital traffic node (Han [32]). The development range of Gwanggyo New Town includes Maetan-dong, Iui-dong, Woncheon-dong, Ha-dong, Uman-dong, and Yeonmu-dong in Suwon-si and Sanghyeon-dong and Yeongdeok-dong in Yongin-Si. The development area is $11,301,699 \mathrm{~m}^{2}$. Gwanggyo New Town is hilly. The hills are about $50-100 \mathrm{~m}$ high and occupy over $78.92 \%$. The gentle slope with a $20^{\circ}$ gradient and the hill occupy $91.8 \%$ of the whole area. The Woncheon and the Yeo streams, which are the primary water resources of Gwanggyo New Town; run from the north to the south and merge into the Hwangguji stream. The Suwon stream is to the west while the Tan, Mabuk and Osan streams are to the east. Seongbok and Dogmak streams are in the south. The water circulation system in Gwanggyo New Town is comprised of a brooklet and recycled storm water. The characteristics are listed in table 9.

Table 9: Gwanggyo New Town water circulation system plan.

\begin{tabular}{|l|l|}
\hline \multicolumn{1}{|c|}{ Plan } & \multicolumn{1}{|c|}{ Contents } \\
\hline $\begin{array}{l}\text { Connecting the stream inside new } \\
\text { town with the urban stream }\end{array}$ & $\begin{array}{l}\text { The stream inside New Town and urban stream can be } \\
\text { connected. }\end{array}$ \\
\hline $\begin{array}{l}\text { The plan for storage, penetration, } \\
\text { and storm water recycle facility. }\end{array}$ & $\begin{array}{l}\text { The plan to use storm water facility site plan is available } \\
\text { to connect it to the water circulation system. }\end{array}$ \\
\hline $\begin{array}{l}\text { Creating an ecological storm water } \\
\text { pond }\end{array}$ & $\begin{array}{l}\text { Creating an eco pond with various functions like water } \\
\text { detention and purification as well as habitat space. }\end{array}$ \\
\hline $\begin{array}{l}\text { Least destructive town layout for } \\
\text { the water canal environment }\end{array}$ & $\begin{array}{l}\text { Prevent the damage to the waterway due to road, parking } \\
\text { lot, and other facilities in the housing estate. }\end{array}$ \\
\hline Using renewable energy & $\begin{array}{l}\text { The use of renewable energy including underground } \\
\text { detention pond and photovoltaic system }\end{array}$ \\
\hline
\end{tabular}

The components of the Gwanggyo New Town waterfront are listed in table 10. The carbon reduction and carbon sequestration components of the waterfront area are listed in table 11.

Table 10: Gwanggyo New Town waterfront plan.

\begin{tabular}{|l|l|}
\hline \multicolumn{1}{|c|}{ Zone } & \multicolumn{1}{c|}{ Components } \\
\hline \multirow{3}{*}{ Stream } & $\begin{array}{l}\text { - Creating the retention and eco ponds } \\
\text { - Habitat composition } \\
\text { - Biotope }\end{array}$ \\
\hline \multirow{3}{*}{ Close-to-Nature River } & $\begin{array}{l}\text { - Use of existing agricultural irrigation canal } \\
\text { - Provide places for relaxation and leisure } \\
\text { - Installation of water purification system } \\
\text { - Constructing a water purification plant }\end{array}$ \\
\hline
\end{tabular}

Data: Korea Environment Institute [28]. 
Table 11: Gwanggyo New Town low carbon landscape resources.

\begin{tabular}{|c|c|c|c|}
\hline \multicolumn{2}{|c|}{ Carbon reduction } & \multicolumn{2}{|c|}{ Carbon sequestration } \\
\hline \multirow{3}{*}{$\begin{array}{l}\text { Energy } \\
\text { conservation }\end{array}$} & $\begin{array}{l}\text { Building layout considering the } \\
\text { water resources }\end{array}$ & \multirow{2}{*}{ Green Network } & Greenway \\
\hline & Pedestrian road & & Eco bridge \\
\hline & $\begin{array}{l}\text { Public transportation and } \\
\text { pedestrian mall }\end{array}$ & \multirow{2}{*}{$\begin{array}{l}\text { Water Resource } \\
\text { System }\end{array}$} & Brooklet \\
\hline \multirow{2}{*}{$\begin{array}{l}\text { Renewable } \\
\text { energy }\end{array}$} & Photovoltaic system & & Detention ponds \\
\hline & Solar thermal system & \multirow{3}{*}{ Waterfront } & Wetland \\
\hline \multirow{3}{*}{$\begin{array}{l}\text { Resource } \\
\text { recycling }\end{array}$} & Recycling heavy water & & Wildlife habitats \\
\hline & Storm water & & Natural river \\
\hline & $\begin{array}{l}\text { Recycling storm water storage } \\
\text { tank }\end{array}$ & \multicolumn{2}{|c|}{ - } \\
\hline
\end{tabular}

Data: Korea Environment Institute [28]

\section{Results}

This study explored the waterfront resources of four New Towns in order to assess their low carbon landscape resources for developing a low carbon city (table 12). The characteristics of water circulation system in each city's waterfront are as follows. Unjeong New Town constructed its water circulation system using water from the Sori-stream, which is a natural river. Many lowlying areas in the Sori-stream basin were prone to floods. To assess the flooding

Table 12: $\quad$ Low carbon landscape resources in urban waterfront.

\begin{tabular}{|c|c|c|c|}
\hline \multicolumn{2}{|r|}{ Carbon reduction } & \multicolumn{2}{|c|}{ Carbon sequestration } \\
\hline \multirow{7}{*}{$\begin{array}{l}\text { Energy } \\
\text { conservation }\end{array}$} & An adobe house & \multirow[b]{2}{*}{ Complex greenery } & Carbon park \\
\hline & $\begin{array}{l}\text { Building arrangement considered } \\
\text { water resources }\end{array}$ & & Vegetable garden \\
\hline & Bicycle activating system & \multirow{2}{*}{$\begin{array}{l}\text { 3-dimensional } \\
\text { planting }\end{array}$} & Slope planting \\
\hline & Pedestrian road & & Roof planting \\
\hline & $\begin{array}{l}\text { Public transportation and pedestrian } \\
\text { mall }\end{array}$ & \multirow{3}{*}{ Green network } & Greenway \\
\hline & $\begin{array}{l}\text { Carbon reduction public } \\
\text { transportation }\end{array}$ & & Ventilation path \\
\hline & Green highway & & Eco bridge \\
\hline \multirow{2}{*}{$\begin{array}{l}\text { Renewable } \\
\text { energy }\end{array}$} & Photovoltaic system & \multirow{2}{*}{$\begin{array}{l}\text { Water } \\
\text { resource system }\end{array}$} & Brooklet \\
\hline & Solar thermal system & & Detention ponds \\
\hline \multirow{4}{*}{$\begin{array}{l}\text { Resource } \\
\text { recycling }\end{array}$} & Using the natural resources & $\begin{array}{l}\text { Water circulation } \\
\text { system }\end{array}$ & Porous pavement \\
\hline & Recycling heavy water & \multirow{5}{*}{ Waterfront } & Wetland \\
\hline & Storm water & & Eco pond \\
\hline & Recycling storm water storage tank & & Rain garden \\
\hline \multirow{2}{*}{\multicolumn{2}{|c|}{ - }} & & Wildlife habitats \\
\hline & & & Natural river \\
\hline
\end{tabular}


problem, the river master plan developed by Korea Land and Housing Corporation was investigated and the planning of the water circulation system was analyzed. Unjung and Geumto streams were the main sources of water supply in Pangyo New Town. The water circulation system was constructed using an existing river. The Pangyo New Town has various characteristic waterfronts including an eco pond, a wetland, and a detention pond inside the complex, which the existing water system utilizes. Before the development in Gimpo Han River New Town, Gamaji stream and Gimpo waterway were used for irrigation. Nevertheless, there was potential for development of the waterfront zone through reorganization and securing an additional water source. Consequently, an eco canal in Gamaji stream and Gimpo waterway, was added to the existing water circulation system. Gwanggyo New Town has the most abundant water resources among the four New Towns. These resources are actively introduced to the water circulation system by applying storm water harvesting and connecting the streams between the housing estate and the urban area.

\section{Conclusion}

Low carbon city is slowly becoming a paradigm for urban development. In order to achieve a low carbon footprint for a city, urban planning using low-carbon landscape elements was introduced. Accordingly, in this study we have defined low carbon landscape and investigated related research trends and carbon landscape classification criteria. Low carbon landscapes are key to creating cities with reduced carbon footprint. Low carbon landscapes methods can be classified as carbon reduction or carbon sequestration and can be systematically analyzed. The results show that low carbon landscape resources were imparted to New Towns due to urban waterfront low carbon landscape design. Social and economic indicators like inherent to the waterfront can be used for further evaluation. However, since this study was limited to other objectives, criteria for selection of low carbon landscape resources have not been verified in terms of their validity and reliability. In future studies, it is necessary to develop an objective index for quantifying low carbon landscape resources and design elements.

\section{Acknowledgements}

This research is supported by the Eco-Innovation Project(Title: Development of wetland construction and ecosystem rehabilitation technologies, Project Number: 416-111-010) of the Ministry of Environment, South Korea and the Basic Science Research Program of the National Research Foundation of Korea (NRF) funded by the Ministry of Education (2013R1A1A2013456).

\section{References}

[1] Lee, M. S. \& Lee, K. B., A Study on the Site Planning to Use Technical Factors of Low \& Zero Carbon Energy Town. Journal of the Architectural Institute of Korea, 29(6), pp. 33-42, 2011. 
[2] Park, J. C. \& Kim, J. Y., Urban Planning Measurements in Pursuit of a Low-carbon Green City- Case Analyses of Basic Planning Elements and Spatial Urban Structures in Korea and Japan - Journal of the Korean Regional Development Association. 22(1), pp. 17-51, 2010.

[3] Ko, J. G., Lee, J. I., Lee, Y. J., Park, E. J., Park, S. H., Kang, S. J., Park, K. C., Kim, E. S., Kim, H. S., Kim, J. H., Um, T. W., O, Y. S. \& Lee Y. J., Local Strategies towards a Low Carbon Society, Hanul Publishing Company: Paju, 2011.

[4] Yeo, I. A. \& Yoon, S. H., E-GIS Database Integration for Applying Low Carbon. Green City Planning - Case Study of Residential Development District in Gwangmyeong, Siheung -. Journal of the Architectural Institute of Korea, 27(10), pp. 277-285, 2011.

[5] NGMS, http://master.gir.go.kr/

[6] Zhang, J. \& Sui, Y.H., Research on Low-carbon Aesthetics Built up by Landscape Design, 2010 International Conference on Environmental Engineering and Applications, eds. S. Baby \& Y. Dan IEEE: NY, pp. 510512. 2010.

[7] Huifang, S., Li, J., Zhu, Q. \& Yu, J., The design and research of landscape architecture based on low-carbon. Proc. of the $2^{\text {nd }}$ International Conference on Multimedia Technology. IEEE: NY, pp. 1800-1803, 2011.

[8] Lee, I. S., Wetland (Marsh, Mud Flat and A Sandy Plain) is a Carbon Pool. Journal of Gyeongnam Development Institute, (-)105, pp. 103-107, 2009.

[9] UNEP,http://www.unep.or.kr/

[10] Kim, Y. J., (A) Critical Analysis of the Lee administration's Low Carbon, Green Growth Policy : From the perspective of sustainable development \& ecological modernization theories. Kyung Hee University Graduate School, 2010.

[11] Ahn, G. Y., Han, S.W. \& Lee, E. H., The Analysis of Instantaneous $\mathrm{CO}_{2}$ Uptake and Evapotranspiration of Herbaceous Plants for Artificial Roof Greening. Korean Journal of Environment and Ecology, 25(1), pp. 91$101,2011$.

[12] Jo, H. K. \& Ahn, T. W., Indicators of Carbon Storage and Uptake by Tree Growth in Natural Ecosystem. Korean Journal of Environment and Ecology, 14(3), pp. 175-182, 2000.

[13] Park, E. J. \& Kang K. Y., Estimation of C Storage and Annual $\mathrm{CO}_{2}$ Uptake by Street Trees in Gyeonggi-do. Korean Journal of Environment and Ecology, 24(5), pp. 591-600, 2010.

[14] Jo, H. K. \& Ahn, T. W., Carbon Storage and Uptake by Deciduous Tree Species for Urban Landscape. Journal of Korean institute of landscape architecture, 40(5): 160-168, 2012.

[15] Neue H. U., Gaunt, J. L., Wang, Z. P., Becker-Heidmann, P. \& Quijano, C., Carbon in tropical wetlands, Geoderma, 79(-), pp. 163-185, 1997.

[16] Persson J., The use of design elements in wetlands. Nordic Hydrology 36(2), pp. 113-120, 2005. 
[17] IPCC, Agriculture, Forestry and Other Land Use. IPCC Guidelines for National Greenhouse Gas Inventories, 4, pp. 7.1-7.23, 2006.

[18] Timothy P. B. \& Paul F. S., Transport of Water, Carbon, and Sediment Through the Yukon River Basin, Usgs Publications Warehouse: Anchorage, AK, 2008.

[19] Beringer, J., Hutley, L. B., Hacker, J. M., Neiniger, B. \& Paw U, K. T., Patterns and processes of carbon, water and energy cycles across northern Australian landscapes: From point to region. Agricultural and Forest Meteorology, 151(11), pp. 1409-1416, 2011.

[20] Zhou, Y., Shi, T., Hu, Y., Gao, C., Liu, M., Fu, S., \& Wang, S., Urban green space planning based on computational fluid dynamics model and landscape ecology principle: a case study of Liaoyang city, northeast China. Chinese Geographical Science 21(4), pp. 465-475, 2011.

[21] Lee, D. G., Landscape Ecology, Bomoondang Publishing Company: Seoul, 2004.

[22] Yoon, S. H., A case study on development of low-carbon city against to the climate change. Korea University Graduate School, 2012.

[23] Costa, L. \& Soares, F., Open space and connectivity in landscape design, 45th ISOCARP Congress. Low carbon cities, ISOCARP: Hague, pp. 1-8, 2009.

[24] ASQASKETS, http://www.asgaskets.com/blog/archives/1190

[25] Seo, E. C., Development of A System Dynamics Model for Evaluating Transportation Carbon Emission. Korea Aerospace University Graduate School, 2011.

[26] Rural Development Administration, The Manual for Rural Amenity Village Planning for Low Carbon Reduction, Rural Development Administration Publications: Suwon, 2010.

[27] Korea Housing Corporation, An Development Plan of Residential Site Development Project in Paju-Unjeong New Town. Report of the Korea Housing Corporation, 2007.

[28] Korea Environment Institute, The Study on the Restoration and Development of Multi-Functional Urban Wetland for the Realization of Future Green City. Report of Korea Environment Institute, 2009.

[29] Korea Housing Corporation, Master Plan and Design Conspectus in Pangyo New Town. Report of the Korea Housing Corporation, 2007.

[30] Korea Housing Corporation, The Study for Establishment of Systematic Water Circulation System in Pangyo New Town. Report of the Korea Housing Corporation, 2005.

[31] Korea Land Corporation, A Residential Site Development Project of Gimpo Han River New Town. Report of Korea Land Corporation, 2009.

[32] Han, I. S., The Study for the Perception Difference of Urban Image in new towns: Focused on Gwanggyo, Dongtan, Segyo new town. Korea University Graduate School, 2011. 